\title{
The Anti-Cancer Effect of a Novel Nutrient Mixture by Inhibiting MMPs Expression, Invasion and Inducing Apoptosis in Chondrosarcoma Cell Line SW-1353
}

\author{
M. W. Roomi ${ }^{1}$, N. W. Roomi ${ }^{1}$, B. Bhanap ${ }^{1}$, A. Niedzwiecki ${ }^{1} \&$ M. Rath ${ }^{1}$ \\ ${ }^{1}$ Dr. Rath Research Institute, Santa Clara, CA, USA \\ Correspondence: Dr. Aleksandra Niedzwiecki, Ph D, Dr. Rath Research Institute, 1260 Memorex Drive, Santa \\ Clara, CA 95050, USA. E-mail: author@drrath.com
}

Received: September 17, 2012 Accepted: October 5, 2012 Online Published: October 30, 2012

doi:10.5539/cco.v1n2p99 URL: http://dx.doi.org/10.5539/cco.v1n2p99

\begin{abstract}
Chondrosarcoma, a malignant tumor of cartilaginous origin is the most frequent adult primary bone cancers. Surgery is the main treatment option because chondrosarcoma typically does not respond to radiation and chemotherapy. Cancer mortality usually results from the local and distant metastasis. A nutrient mixture containing ascorbic acid, lysine, proline, green tea extract, was tested on chondrosarcoma cells SW-1353 for viability, matrix metalloproteinase expression, Matrigel invasion, morphology and apoptosis. The SW-1353 cells were grown in appropriate media and treated with the nutrient mixture at 10, 50, 100, 500 and $1000 \mu \mathrm{g} / \mathrm{ml}$ concentrations. Cells were also treated with PMA $(100 \mathrm{ng} / \mathrm{ml})$ for MMP-9 stimulation. Cell proliferation was carried out by MTT assay, MMPs by zymography, invasion through Matrigel. Morphology and apoptosis were also conducted. The nutrient mixture did not exhibit toxicity at $100 \mu \mathrm{g} / \mathrm{ml}$, but showed $40 \%$ inhibition at 1000 $\mu \mathrm{g} / \mathrm{ml}$. Zymography demonstrated two bands, for MMP-2 and MMP-9. PMA treatment further enhanced MMP-9 expression. The nutrient mixture inhibited expression of both MMPs in a dose dependent manner. Matrigel invasion was reduced by $40 \%, 70 \%, 88 \%$ and $100 \%$ at $50,100,500$ and $1000 \mu \mathrm{g} / \mathrm{ml}$ respectively. The nutrient mixture induced slight apoptosis at $250 \mu \mathrm{g} / \mathrm{ml}$, moderate at $500 \mu \mathrm{g} / \mathrm{ml}$ and significant at $1000 \mu \mathrm{g} / \mathrm{ml}$ concentrations. Morphology showed slight changes at the highest concentrations. The nutrient mixture significantly inhibited all the important hallmarks for cancer progression, suggesting that it has a possibility for exploration as a significant therapeutic entity in chondrosarcoma.
\end{abstract}

Keywords: chondrosarcoma, nutrient mixture, MMP, Matrigel invasion, apoptosis

\section{Introduction}

Chondrosarcoma, a malignant tumor of cartilage cells mainly affecting adults between 30-60 years. According to the American Cancer Society 2012 estimates, chondrosarcoma has become the most common primary bone cancer accounting for more than $40 \%$ of the adult primary bone tumor cases. It grows in the chondrocytes (cartilage cells), and mainly affects the legs, upper arms, scapula, ribs and pelvic bones. Although the exact cause of chondrosarcoma is not known, it is postulated that individuals with certain genetic or chromosomal abnormalities are at increased risk. Grade and stage are the most important and independent prognostic factors for survival in chondrosarcoma. Cancer mortality usually occurs from tumor invasion resulting in local or distant metastasis to vital organs. High-grade chondrosarcoma has much poorer prognosis. 10-year survival of high-grade chondrosarcoma was calculated to be 38\% (Fiorenza et al., 2002). Recurrence is based on irregular tumor margins and lesions greater than $10 \mathrm{~cm}$. Surgery is generally the main treatment option for chondrosarcoma. Chemotherapy or radiation therapies are not very effective and are rarely given in cases of extensive metastasis (Gelderblom et al., 2008). The high metastatic potential and inadequate treatment methods leading to poor outcomes, require an urgent need to develop more effective less toxic treatment alternatives.

We have developed strategies to inhibit cancer growth and expansion using naturally occurring nutrients including lysine, proline, ascorbic acid, green tea extract, and others. According to Rath and Pauling research (1992), nutrients such as lysine and ascorbic acid have been suggested to act as natural inhibitors of extra cellular matrix (ECM) degradation, and as such have potential to modulate tumor growth and expansion. These nutrients can exert their effects by strengthening the connective tissue surrounding cancer cells by increasing collagen 
synthesis, as well as inhibit the expression of matrix metalloproteinase (MMP) enzymes. In our previous studies, these nutrients (the nutrient mixture, NM) have exhibited broad spectrum therapeutic and chemoprotective activities in vitro and in vivo in a number of cancer cell lines. This synergistic anticancer effects of the NM was observed by inhibition of cancer cells growth, expression of MMPs, Matrigel invasion, metastasis, and angiogenesis (Roomi et al., 2006, 2007, 2009a, 2009b). Considering the efficacy of NM on other cancer cell lines, we investigated the effects of NM on the human chondrosarcoma cell line SW-1353. We hypothesized that NM would significantly inhibit the growth, MMP expression and invasion of the SW-1353 cancer cell line.

\section{Materials and Methods}

\subsection{Composition of Nutrient Mixture}

The composition of the nutrient mixture (NM) and the proportion included the following: Vitamin $\mathrm{C}$ (as ascorbate salts of $\mathrm{Mg}, \mathrm{Ca}$ and plamitate) $710 \mathrm{mg}$; L-lysine $1000 \mathrm{mg}$; L-Proline $750 \mathrm{mg}$; L-Arginine $500 \mathrm{mg}$; N-Acetyl Cysteine 200mg; Standardized Green Tea Extract (80\% polyphenol) $1000 \mathrm{mg}$; Selenium $30 \mu \mathrm{g}$; Copper $2 \mathrm{mg}$; and Manganese $1 \mathrm{mg}$.

\subsection{Cancer Cells and Culture}

Chondrosarcoma cells line, SW-1353 was from American Type Culture Collection (ATCC, Rockville, MD), and grown in modified Dulbecco's Eagle medium supplemented with $10 \%$ fetal bovine serum, $100 \mathrm{U} / \mathrm{ml}$ penicillin and $100 \mu \mathrm{g} / \mathrm{ml}$ streptomycin (Gibco BRL, Long Island, NY) in 24-well tissue culture plates (Costar, Cambridge, MA). Cells were incubated in $1 \mathrm{ml}$ of media at $37^{\circ} \mathrm{C}$ in a tissue culture incubator equilibrated with $95 \%$ air and $5 \% \mathrm{CO}$. At near confluence, the cells were treated with the NM, dissolved in the media and tested in triplicate: $0,10,50,100,500$ and $1000 \mu \mathrm{g} / \mathrm{ml}$. Cells were also treated with Phorbol Myristate Acetate (PMA) $100 \mathrm{ng} / \mathrm{ml}$ to enhance MMP-9 expression. The plates were then returned to the incubator.

\subsection{MTT Assay}

Cell viability was carried out by MTT assay. The colorimetric assay based on the ability of viable cells to reduce a soluble yellow tetrazolium salt [3-(4,5-dimethylthiazol-2-yl) 2,5-diphenyl tetrazilium bromide] (MTT) to a blue formazan crystal by mitochondrial succinate dehydrogenase activity of viable cells. This method is a good index of mitochondrial activity and thus of cell viability. After a 24 hour incubation, the cells were washed with phosphate buffered saline (PBS) and $500 \mu \mathrm{l}$ of MTT (Sigma\#M-2128) $0.5 \mathrm{mg} / \mathrm{ml}$ in media was added. After addition the plates were returned to the $37^{\circ} \mathrm{C}$ incubator for 2 hours. After which, the supernatant was removed, 1 $\mathrm{ml}$ of DMSO was added, and absorbance was read at $570 \mathrm{~nm}$ in Bio Spec 1601, Shimadzu spectrometer. The OD570 of the DMSO solution in each well was considered to be proportional to the number of cells. The OD of the control (treatment without supplement) was considered $100 \%$.

\subsection{Gelatinase Zymography Enzyme Activity Assay}

Gelatinase zymography was carried out in 10\% Novex Pre-Case SDS Polyacrylamide Gel (Invitrogen Corporation) in the presence of $0.1 \%$ gelatin under non-reducing conditions. Culture media $(20 \mathrm{ml})$ were mixed with sample buffer and loaded for SDS Plyacrylamide Gel Electrophoresis (SDS-PAGE) was performed as suggested by the manufacturer (Novex). Samples were not heated before electrophoresis. Following electrophoresis the gels were washed twice in $2.5 \%$ Triton X-100 for 30 minutes to remove SDS. The gels were then incubated at $37^{\circ} \mathrm{C}$ overnight in $\mathrm{CaCl}_{2}$ at $\mathrm{pH} 8.0$ and stained with $0.5 \%$ Coomassie Blue $\mathrm{R} 250$ dissolved in $50 \%$ methanol and $10 \%$ glacial acetic acid and destained. Upon renaturation of the enzyme, the gelatinases digested the gelatin in the gel, producing clear bands against an intensely stained background. Protein standards were also ran and approximate molecular weights werecalculated. Gelatinase zymograms were scanned using CanoScan 9950F Canon scanner at 1,200 dpi. The intensity of the bands was evaluated using a pixel-based densitometer program Un-Scan-It, Version 5.1, 32-bit, (Silk Scientific Corporation) at a resolution of 1 Scanner Unit (1/100 dpi), and expressed as a percentage of control.

\subsection{Matrigel Invasion Assay}

Invasion studies were conducted using Matrigel (Becton Dickinson) inserts in 24-well plates. Suspended in medium, SW-1353 cells were supplemented with the NM and seeded into the inserts in the well. Thus, both the medium on the insert and in the well had the same supplements. The plates were then returned to the incubator and equilibrated with $95 \%$ room air and $5 \% \mathrm{CO}_{2}$. After incubation, the media from the wells were drawn. The cells on the upper surface of the inserts were gently scrubbed away with cotton swabs. The cells that had penetrated the Matrigel membrane and migrated onto the lower surface of the Matrigel were stained with hematoxylin and eosin ( $\mathrm{H} \& \mathrm{E})$ and counted under the microscope. 


\subsection{Morphology and Apoptosis}

Morphology of the cells cultured in test concentrations of were evaluated after 24 hours by H\&E staining and apoptosis using Live Green Caspase Detection Kit and photographed by microscope. The SW-1353 cells were challenged with NM dissolved in media at the experimental doses and incubated for 24 hours. The cell culture was washed with PBS and treated with the caspase reagent as suggested by the manufacturer (Molecular Probes Image-IT Live Green Poly Caspases Detection Kit 135104, Invitrogen). The photographs were taken with a fluorescence microscope and cells were counted. Green-colored cells represent viable cells, while yellow orange and red represents early and late apoptosis respectively.

\subsection{Data Analysis}

The results were expressed as mean \pm standard deviation. Data was analyzed by independent t-test. Significance was determined at $\mathrm{p}<0.05$.

\section{Results}

\subsection{Cell Proliferation}

Figure 1 shows the effects of NM relative to control in triplicate of the Chondrosarcoma cell line. NM was not toxic to chondrosarcoma cell line SW-1353 at $100 \mu \mathrm{g} / \mathrm{ml}$, but exhibited $10 \%$ and $40 \%(\mathrm{p}<0.001)$ toxicity at both 500 and $1000 \mu \mathrm{g} / \mathrm{ml}$, respectively.

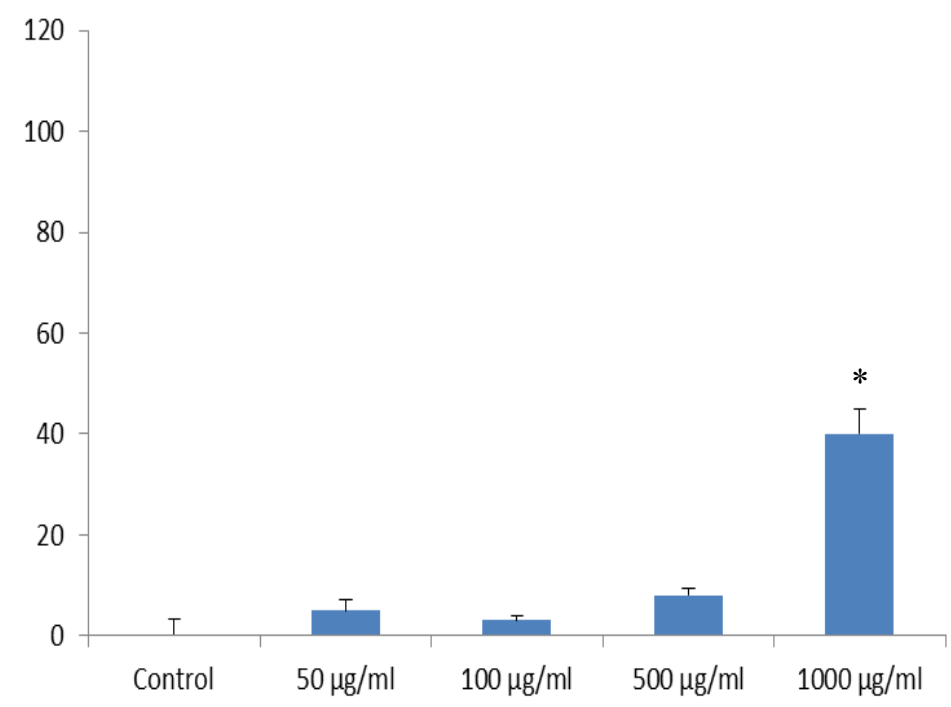

Figure 1. Effect of the NM on chondrosarcoma cell line SW-1353 proliferation

The cell proliferation was inhibited $10 \%$ at $500 \mu \mathrm{g} / \mathrm{ml}$ and $40 \%$ at $1000 \mu \mathrm{g} / \mathrm{ml}$. (* Significant at $\mathrm{p}<0.001$ )

\subsection{Gelatinase Zymography}

Zymography demonstrated two bands corresponding to MMP-2 and MMP-9. PMA (Phorbol Myristate Acetate) treatment stimulated MMP-9 expression. NM inhibited the expression of both MMP-2 and MMP-9 in a dose-dependent fashion; $50 \%$ at $100 \mu \mathrm{g} / \mathrm{ml}$ and $100 \%$ at $500 \mu \mathrm{g} / \mathrm{ml}$ (Figure 2A and 2B). Densitometry analysis of MMP-2 for untreated SW-1353 cells showed inhibition of $56 \%$ at $100 \mu \mathrm{g} / \mathrm{ml}$ and $98 \%$ at $500 \mu \mathrm{g} / \mathrm{ml}$ of NM. Regression analysis showed a linear trend of $\mathrm{R} 2=0.85$ (Figure 2C). For SW-1353 cells treated with PMA, MMP-2 inhibition was seen as follows: $97 \%$ at $50 \mu \mathrm{g} / \mathrm{ml}, 98 \%$ at $100 \mu \mathrm{g} / \mathrm{ml}$ and $100 \%$ at $500 \mu \mathrm{g} / \mathrm{ml}$. Regression was noted at R2 $=0.81$ (Figure 2D). Untreated SW- 1353 cells showed an inhibition of MMP-9 expression of 33\% at $10 \mu \mathrm{g} / \mathrm{ml}, 98 \%$ at $50 \mu \mathrm{g} / \mathrm{ml}, 99 \%$ at $100 \mu \mathrm{g} / \mathrm{ml}$ and $100 \%$ at $500 \mu \mathrm{g} / \mathrm{ml}$. R2 for these cells was 0.88 (Figure 2C). Finally, for the SW-1353 cells treated with PMA, an equally strong inhibition of expression of MMP-9 was observed. MMP-9 expression was inhibited by $82 \%$ at $50 \mu \mathrm{g} / \mathrm{ml}$ of NM, $83 \%$ at $100 \mu \mathrm{g} / \mathrm{ml}$ and $99 \%$ at 500 $\mu \mathrm{g} / \mathrm{ml}$. Regression coefficient for PMA-induced MMP-9 expression of SW-1353 cells was calculated to be $\mathrm{R} 2=0.86$ (Figure 2D). 
2A- Normal SW-1353 cells

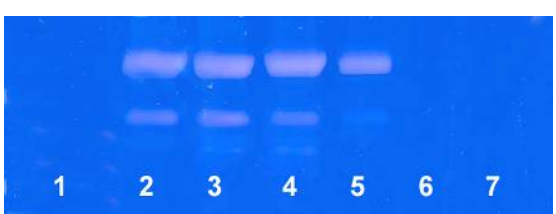

2B- SW-1353 cells treated with PMA

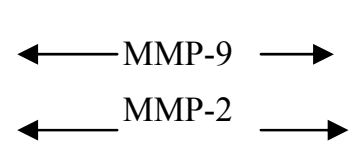

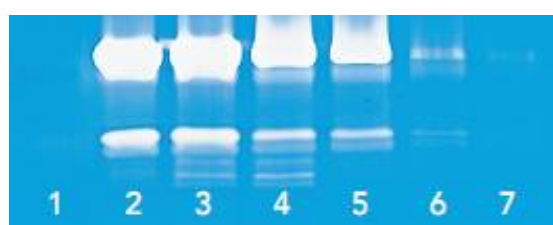

The upper row corresponds to MMP-9 secretion and the lower line to MMP-2. Each column corresponds to increasing concentration of NM, (Lane 1:Marker, 2:Control, Lanes 3-7: NM doses 10, 50, 100, 500 and 1,000 $\mu \mathrm{g} / \mathrm{ml}$ )

2C. Densitometry of MMP-2 and MMP-9 of SW-1353 cells. $\mathrm{R}^{2}$ represents a linear regression analysis of the dose-dependent inhibition of MMP

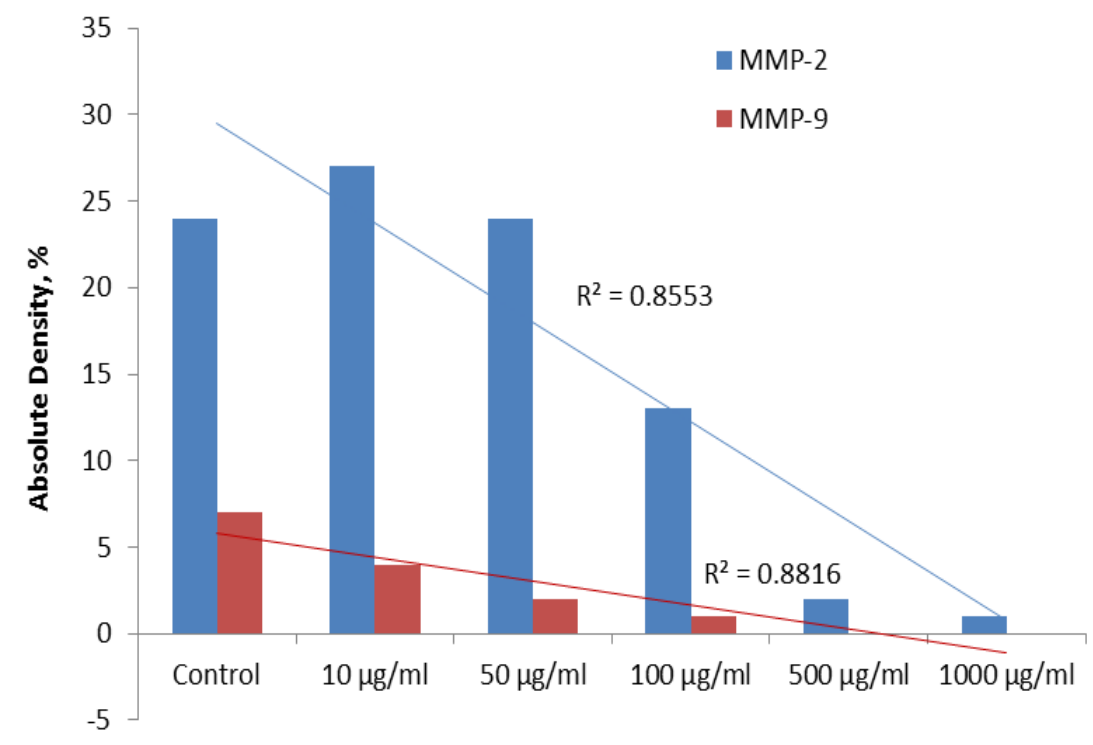

NM Concentration

2D. Densitometry analysis of MMP-2 and MMP-9 of PMA (100 ng/ml) treated SW-1353 cells

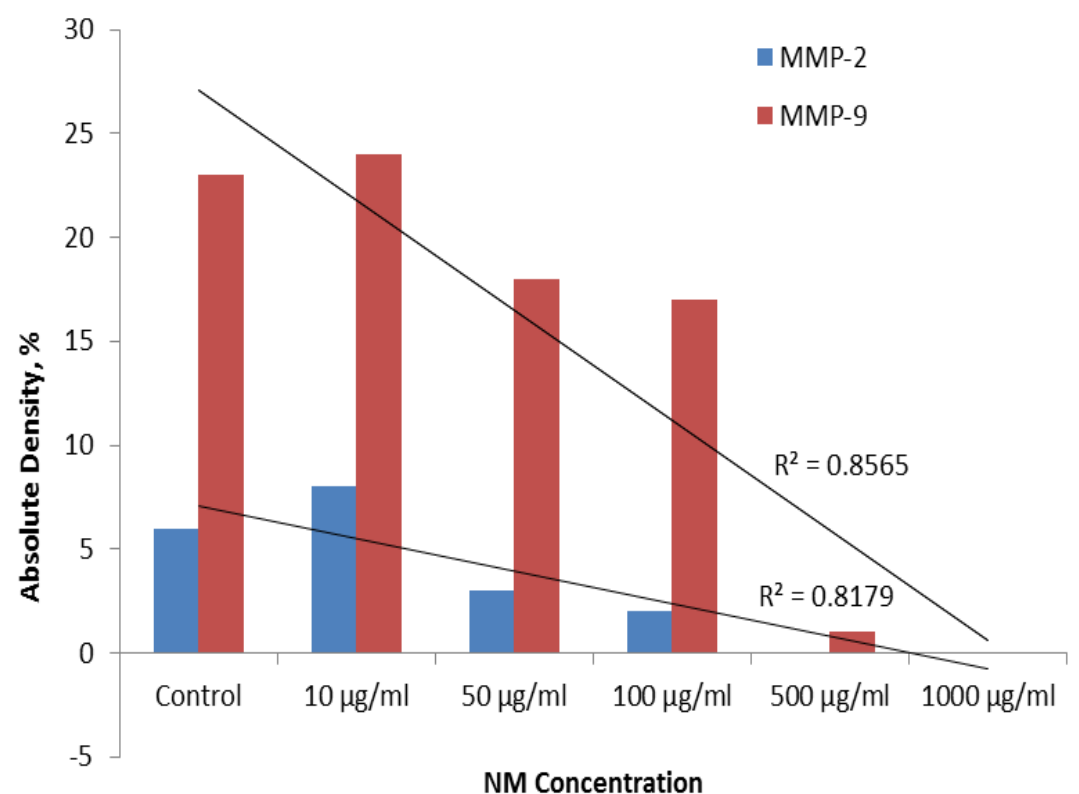

Figure 2. Effect of NM on MMP-2 and MMP-9 secretion by chondrosarcoma cell line SW 1353 


\subsection{Matrigel Invasion}

Figure 3 (A-E) reveals a significant dose-dependent inhibition of SW-1353 cell migration and invasion through Matrigel membrane. $38 \%$ inhibition was observed at $50 \mu \mathrm{g} / \mathrm{ml}, 65 \%$ at $100 \mu \mathrm{g} / \mathrm{ml}, 85 \%$ at $500 \mu \mathrm{g} / \mathrm{ml}$ and $100 \%$ inhibition was noted at $1000 \mu \mathrm{g} / \mathrm{ml}$ of $\mathrm{NM}$ concentration, $\mathrm{p}<0.001$ (Figure $3 \mathrm{~F}$ ).

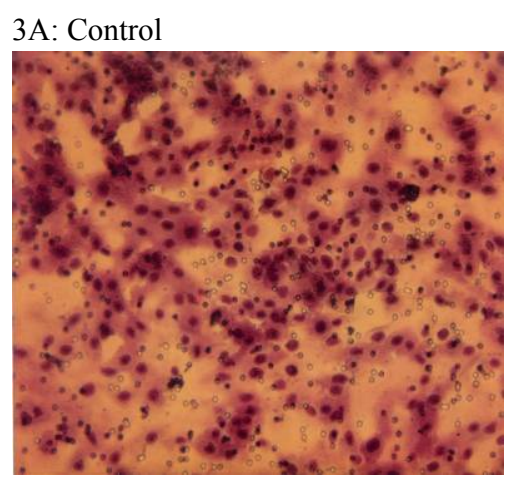

3D: NM $500 \mu \mathrm{g} / \mathrm{ml}$

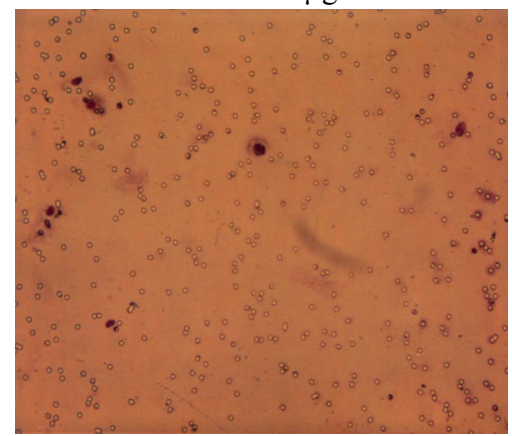

3F: Effect of NM Matrigel invasion on SW-1353 cells (* Significance $p<0.001$ with respect to control)

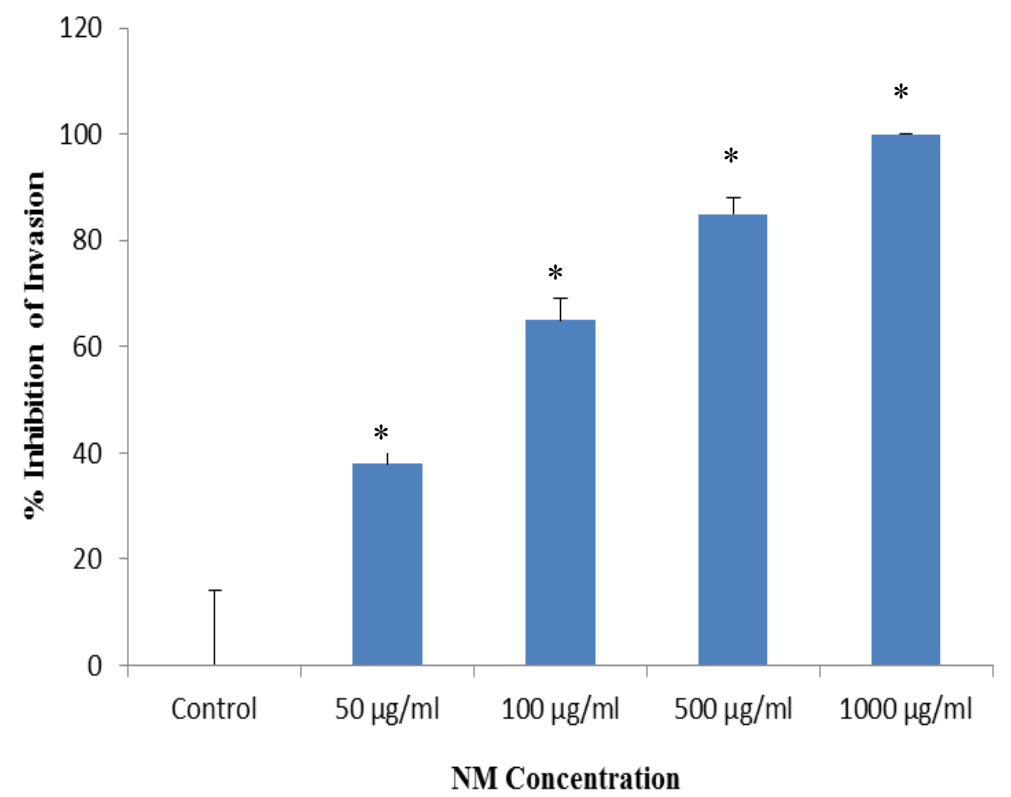

Figure 3. Effect of NM on chondrosarcoma cell line SW-1353 invasion through Matrigel (Magnification 10x)

\subsection{Morphology and Apoptosis}

H\&E staining of SW-1353 cells exposed to NM showed no changes at the $50 \mu \mathrm{g} / \mathrm{ml}$ and $100 \mu \mathrm{g} / \mathrm{ml}$ doses but showed slight changes at the $500 \mu \mathrm{g} / \mathrm{ml}$ dose (Figure $4 \mathrm{~A}-\mathrm{E}$ ). These changes include, shrinking of the cytoplasm, 
darkly stained nuclei and intensely acidophilic cytoplasm suggest cells undergoing apoptosis. Using the live green caspase kit, a dose-dependent apoptosis of the SW-1353 cells was evident with the NM. Figure 5 (A-E) highlights that as the concentration of NM was increased the apoptotic events also increased. A quantitative analysis of this is represented in Figure $5 \mathrm{~F}$, which shows concentration of live cells gradually decreased as the NM dose increased. At $250 \mu \mathrm{g} / \mathrm{ml}$ of NM, $81 \%$ cells were live, however at $500 \mu \mathrm{g} / \mathrm{ml}$ only $37 \%$ cells were live and $62 \%$ were either in early or late apoptosis. At $1000 \mu \mathrm{g} / \mathrm{ml}, 10 \%$ cells were live, while $90 \%$ cells were in early and late apoptosis stage.

4A: Control

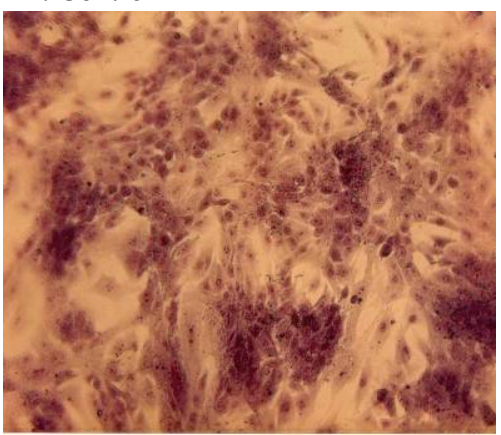

4D: NM-500 $\mu \mathrm{g} / \mathrm{ml}$

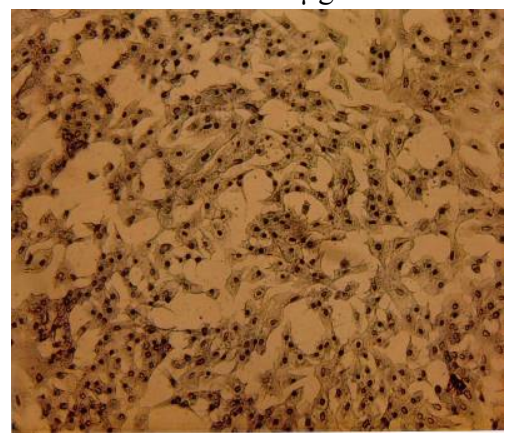

4B: NM $50 \mu \mathrm{g} / \mathrm{ml}$

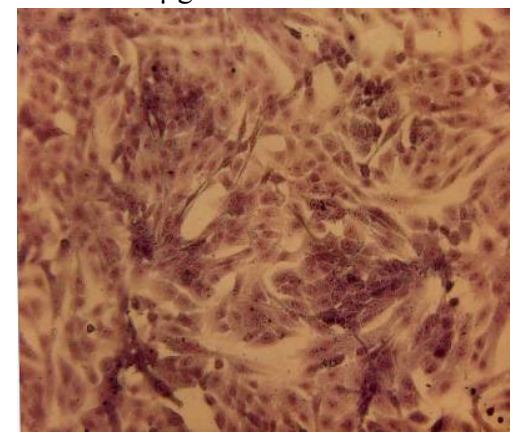

4C: NM-100 $\mu \mathrm{g} / \mathrm{m}$

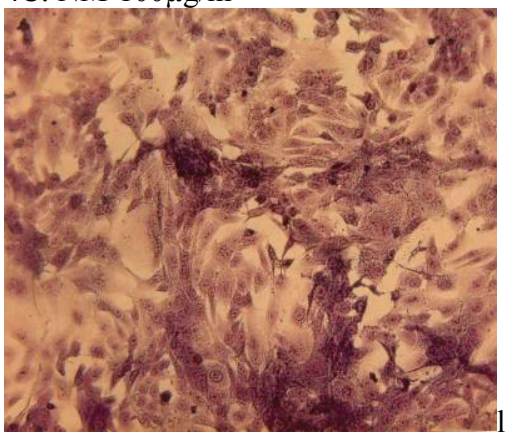

4E: NM-1000 $\mu \mathrm{g} / \mathrm{ml}$

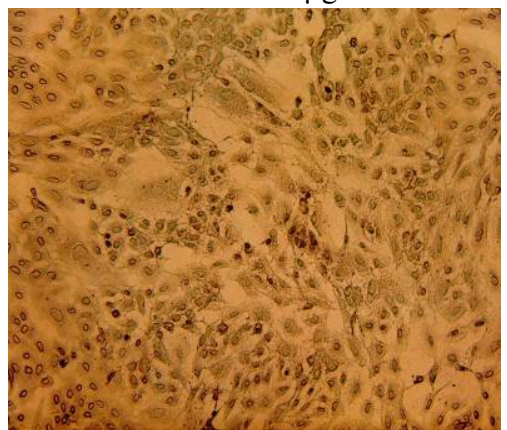

Figure 4. SW 1353 cell morphology showed slight changes at the higher concentrations

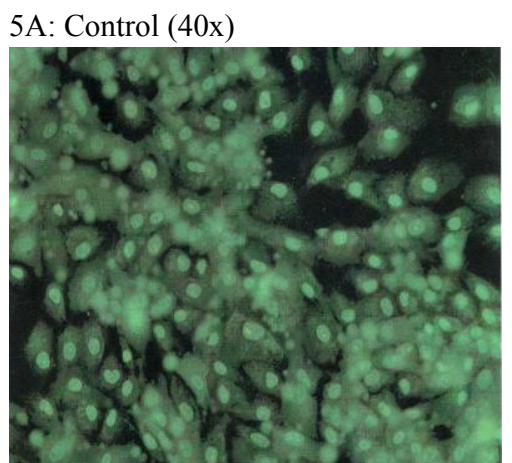

5D: $\mathrm{NM} 500 \mu / \mathrm{ml}(100 \mathrm{x})$

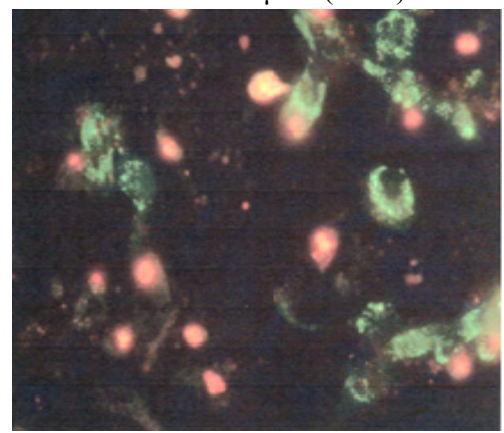

5B: NM 100 $\mu \mathrm{g} / \mathrm{ml}(100 \mathrm{x})$

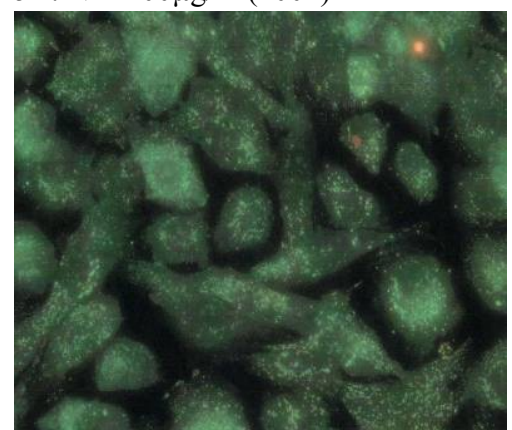

5C: NM $250 \mu \mathrm{g} / \mathrm{ml}(100 \mathrm{x})$

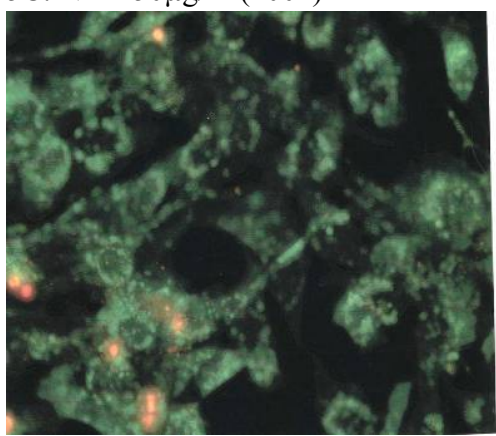

5E: NM $1000 \mu \mathrm{g} / \mathrm{ml}(100 \mathrm{x})$

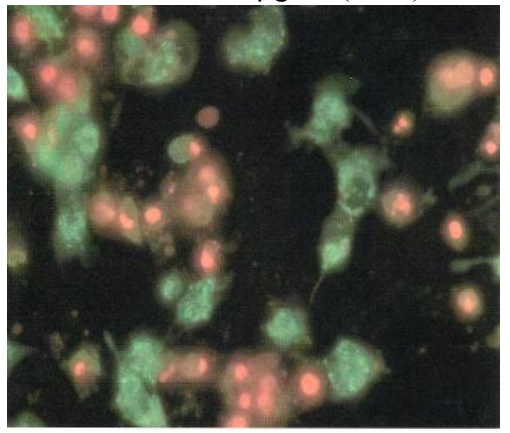


Figure 5F: Quantitative analysis of apoptotic events in SW-1353 cells exposed to NM

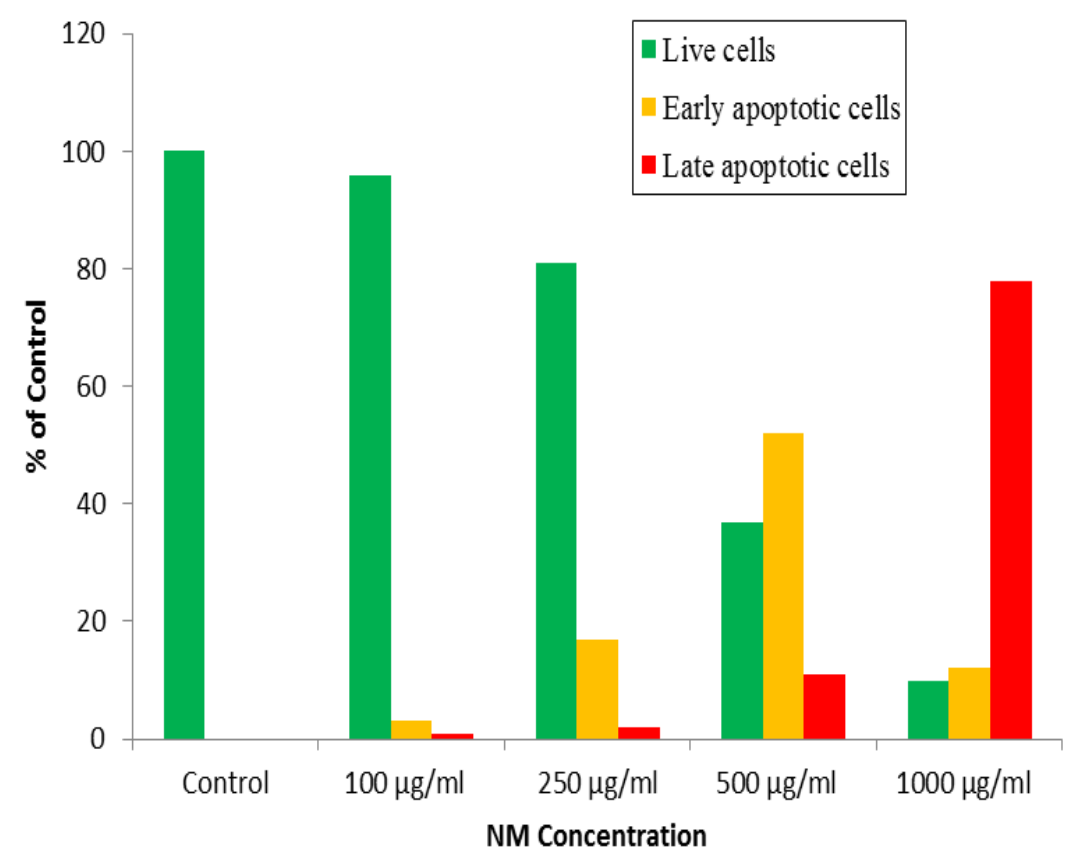

Figure 5. Photomicrograph of apoptotic events using live green caspase at increasing concentrations of NM

\section{Discussion}

The results of our experiments on the chondrosarcoma cell line SW-1353 suggest that NM is effective in inhibiting cell proliferation above a concentration of $500 \mu \mathrm{g} / \mathrm{ml}$. Additionally, a dose-dependent decrease in MMP expression and Matrigel migration was observed. Furthermore, NM also induced apoptosis. These are the most important steps in cancer invasion and metastasis.

The NM formulation was based upon several important nutrients that exhibited anti-cancer properties, in particular those that reinforce the ECM, inhibit MMP activity and are cytotoxic to cancer cells. For example, ascorbic acid and the amino acids lysine and proline are critical to proper ECM formation and structural integrity by ensuring synthesis and hydroxylation of collagen fibers (Roomi et al., 2005). Lysine possesses an additional role in maintaining proper collagen formation by inhibiting proteolysis (Rath \& Pauling, 1992). Green tea extract has shown promise in controlling cancer growth, metastasis and angiogenesis (Taniguchi et al., 1992; Valcic et al., 1996; Yang et al., 1998; Mukhtar \& Ahmed, 2000). N-acetylcysteine is known to inhibit MMP-9 and invasive activities of tumor cells (Morini et al., 1999; Kawakami, Kageyama, Fujii, Kihara, \& Oshima, 2001). In addition to regulating ECM properties, certain nutrients can induce cell death. Ascorbic acid, for example, is known to inhibit cell division and growth via hydrogen peroxide production (Maramag, Menon, Balaji, Reddy, \& Laxmanan, 1997). Arginine, a known precursor of nitrogen oxide, also plays an important role in cell apoptosis induction (Cooke \& Dzau, 1997). Finally, selenium has been shown to inhibit the secretion of MMP secretion and tumor invasion (Yoon, Kim, \& Chung, 2001).

These nutrients can exert their effects by strengthening the connective tissue surrounding cancer cells by influencing collagen synthesis, as well as inhibit the expression of MMP enzymes. Free radical injury plays a key role in cancer initiation and progression. During the multistep process, the degradation of ECM by MMPs is a critical step in tumor growth, invasion, and metastasis. It is important to restrict this step to halt tumor progression. Matrix metalloproteinases are a family of proteolytic enzymes able to degrade connective tissue and are associated with cancer metastasis and tumor angiogenesis. Two key enzymes, MMP-2 and MMP-9, play a key role in the degradation of collagen types II and IV, important components of the ECM. Higher expression of MMP enzymes is shown to play a role in the malignancy potential of chondrosarcomas. When high-grade chondrosarcoma samples were compared to lower-grade samples using immunohistochemistry, the ratio (grade 3 to grade 1) of gene expression of MMP-2 exceeded (Boeuf, Bovée, Lehner, Hogendoorn, \& Richter, 2010). In a comparison of MMP-2 and MMP-9 expression of normal cartilage and chondrosarcoma tissue, the chondrosarcoma cells samples had a higher expression of MMPs (Moses \& Shing, 1994). Elliot et al. (2002) 
showed that Bcl-3, inhibitor of NF-kappaB1 can cooperate to activate MMP-1 transcription of chondrosarcoma cells SW 1353. In another study, Elliot's group also showed that synthetic triterpenoid, CDDO, inhibited IL-1 induced MMP-1 and MMP-13 expression in SW-1353 cells (Elliott et al., 2003). While Burrage et al. evaluated the effect of synthetic ligand LG 100268 for nuclear hormone receptor and it selectively inhibit IL-1 and stimulate MMP-1 and MMP-13 (Burrage et al., 2007).

Our studies demonstrated significant inhibition of MMP-2 and MMP-9 expression, the important mediators of angiogenesis and metastasis. These data suggest NM may have a role in the therapeutic approaches of chondrosarcoma, specifically by targeting MMP expression and thereby inhibiting migration of chondrosarcoma within the ECM as well as stabilizing the ECM surrounding an encapsulated tumor, thereby reducing chances of metastasis. In addition, NM maximally inhibits the proliferation of cancer cells at high doses, inhibits Matrigel invasion and induces apoptotic changes at the cellular level. The effect appears to be cancer-specific since our previous studies demonstrated no NM toxicity on a variety of normal cells, such as fibroblasts, smooth muscle cells and endothelial cells (Ivanov, Ivanova, \& Niedzwiecki, 1997; Ivanov et al., 2007). Furthermore, the NM has also been shown to be safe in vivo. In a previous in vivo study, we found that gavaging adult female ODS rats with the NM (at 3,90 and $150 \mathrm{mg}$ per day for seven days), had no adverse effects on vital organs such as the heart, liver, and kidneys. In the same study, the NM did not affect the associated serum enzymes indicating that this mixture is safe to use even at higher doses, by far exceeding the normal equivalent doses of this combination (Roomi et al., 2003). Overall, the NM may offer a therapeutic benefit and play a role in support of chondrosarcoma.

\section{Acknowledgements}

Dr. Rath Health Foundation provided funding for the research study. Catherine Flowers provided proofreading assistance.

\section{References}

Boeuf, S., Bovée, J. V., Lehner, B., Hogendoorn, P. C., \& Richter, W. (2010). Correlation of hypoxic signalling to histological grade and outcome in cartilage tumours. Histopathology, 56(5), 641-51. http://dx.doi.org/10.1111/j.1365-2559.2010.03528.x

Burrage, P. S., Huntington, J. T., Sporn, M. B., \& Brinckerhoff, C. E. (2007). Regulation of matrix metalloproteinase gene expression by a retinoid X receptor-specific ligand. Arthritis Rheum, 56(3), 892-904. http://dx.doi.org/10.1002/art.22417

Cooke, J. P., \& Dzau, V. J. (1997). Nitric oxide synthase: role in the genesis of vascular disease. Annu Rev Med, 48, 489-509. http://dx.doi.org/10.1146/annurev.med.48.1.489

Elliott, S. F., Coon, C. I., Hays, E., Stadheim, T. A., \& Vincenti, M. P. (2002). Bcl-3 is an interleukin-1-responsive gene in chondrocytes and synovial fibroblasts that activates transcription of the matrix metalloproteinase 1 gene. Arthritis Rheum, 46(12), 3230-9.

Elliott, S., Hays, E., Mayor, M., Sporn, M., \& Vincenti, M. (2003). The triterpenoid CDDO inhibits expression of matrix metalloproteinase-1, matrix metalloproteinase-13 and Bcl-3 in primary human chondrocytes. Arthritis Res Ther, 5(5), R285-91. http://dx.doi.org/10.1186/ar792

Fang, J., Shing, Y., Wiederschain, D., Yan, L., Butterfield, C., Jackson, G., .. Moses, M. A. (2000). Matrix metalloproteinase-2 is required for the switch to the angiogenic phenotype in a tumor model. Proc Natl Acad Sci USA, 97(8), 3884-9. http://dx.doi.org/10.1073/pnas.97.8.3884

Fiorenza, F., Abudu, A., Grimer, R. J., Carter, S. R., Tillman, R. M., Ayoub, K., ... Davies, A. M. (2002). Risk factors for survival and local control in chondrosarcoma of bone. J Bone Joint Surg Br, 84(1), 93-9. http://dx.doi.org/10.1302/0301-620X.84B1.11942

Gelderblom, H., Hogendoorn, P. C., Dijkstra, S. D., van Rijswijk, C. S., Krol, A. D., Taminiau, A. H., \& Bovée, J. V. (2008) The clinical approach towards chondrosarcoma. Oncologist, 13(3), 320-9. http://dx.doi.org/10.1634/theoncologist.2007-0237

Gokaslan, Z. L., Chintala, S. K., York, J. E., Boyapati, V., Jasti, S., Sawaya, R., ... Rao, J. S. (1998). Expression and role of matrix metalloproteinases MMP-2 and MMP-9 in human spinal column tumors. Clin Exp Metastasis, 16(8), 721-8. http://dx.doi.org/10.1023/A:1006580728338

Ivanov, V., Ivanova, S., Roomi, M. W., Kalinovsky, T., Niedzwiecki, A., \& Rath, M. (2007). Naturally produced extra-cellular matrix inhibits growth rate and invasiveness of human osteosarcoma cancer cells. Med Oncol, 24, 209-217. http://dx.doi.org/10.1007/BF02698042 
Ivanov, V. O., Ivanova, S. V., \& Niedzwiecki, A. (1997). Ascorbate affects proliferation of guinea-pig vascular smooth muscle cells by direct and extracellular matrix-mediated effects. J Mol Cell Cardiol, 29, 3293-3303. http://dx.doi.org/10.1006/jmcc.1997.0555

Kawakami, S., Kageyama, Y., Fujii, Y., Kihara, K., \& Oshima, H. (2001). Inhibitory effect of N-acetylcysteine on invasion and MMP-9 production of T24 human bladder cancer cells. Anticancer Res, 21(1A), 213-9.

Kawashima, A., Okada, Y., Nakanishi, I., Ueda, Y., Iwata, K., \& Roessner, A. (1997). Immunolocalization of matrix metalloproteinases and tissue inhibitors of metalloproteinases in human chondrosarcomas. Gen Diagn Pathol, 142(3-4), 129-37.

Maramag, C., Menon, M., Balaji, K. C., Reddy, P. G., \& Laxmanan, S. (1997). Effect of vitamin C on prostate cancer cells in vitro: effect on cell number, viability, and DNA synthesis. Prostate, 32(3), 188-95. http://dx.doi.org/10.1002/(SICI)1097-0045(19970801)32:3<188::AID-PROS5>3.0.CO;2-H

Morini, M., Cai, T., Aluigi, M. G., Noonan, D. M., Masiello, L., De Flora, S., ... Fassina, G. (1999). The role of the thiol $\mathrm{N}$-acetylcysteine in the prevention of tumor invasion and angiogenesis. Int J Biol Markers, 14(4), $268-71$.

Moses, M. A., \& Shing, Y. (1994). Production of matrix metalloproteinases and a metalloproteinase inhibitor by swarm rat chondrosarcoma. Biochem Biophys Res Commun, 199(1), 418-24. http://dx.doi.org/10.1006/bbrc.1994.1245

Mukhtar, H., \& Ahmad, N. (2000). Tea polyphenols: prevention of cancer and optimizing health. Am J Clin Nutr, 71(6 Suppl), 1698S-702S; discussion 1703S-4S.

Rath, M., \& Pauling, L. (1992). Plasmin-induced proteolysis and the role of apoprotein (a), lysine and synthetic analogs. Orthomolecular Med, (7), 17-23.

Roomi, M. W., Ivanov, V., Kalinovsky, T., Niedzwiecki, A., \& Rath, M. (2007). Inhibition of cell invasion and MMP production by a nutrient mixture in malignant liposarcoma cell line SW-872. Med Oncol, 24(4), 394-401. http://dx.doi.org/10.1007/s12032-007-0022-z

Roomi, M. W., Ivanov, V., Netke, S. P., Niedzwiecki, A., \& Rath, M. (2003). Serum Markers of the Liver, Heart, and Kidney and Lipid Profile and Histopathology in ODS Rats Treated With Nutrient Synergy. Journal of the American College of Nutrition, Abstract \#86, 22(5), 477.

Roomi, M. W., Roomi, N., Ivanov, V., Kalinovsky, T., Niedzwiecki, A., \& Rath, M. (2005). Inhibitory effect of a mixture containing ascorbic acid, lysine, proline and green tea extract on critical parameters in angiogenesis. Oncol Rep, 14(4), 807-15.

Roomi, M. W., Roomi, N., Ivanov, V., Kalinovsky, T., Niedzwiecki, A., \& Rath, M. (2006). Inhibition of pulmonary metastasis of melanoma b16fo cells in C57BL/6 mice by a nutrient mixture consisting of ascorbic Acid, lysine, proline, arginine, and green tea extract. Exp Lung Res, 32(10), 517-30. http://dx.doi.org/10.1080/01902140601098552

Roomi, M. W., Roomi, N. W., Kalinovsky, T., Rath, M., \& Niedzwiecki, A. (2009b). Antiangiogenic properties of a nutrient mixture in a model of hemangioma. Exp Oncol, 31(4), 214-9.

Roomi, M. W., Roomi, N. W., Kalinovsky, T., Rath, M., \& Niedzwiecki, A. (2009a). Marked inhibition of growth and invasive parameters of head and neck squamous carcinoma FaDu by a nutrient mixture. Integr Cancer Ther, 8(2), 168-76.

Sakamoto, A., Oda, Y., Iwamoto, Y., \& Tsuneyoshi, M. (1999). Expression of membrane type 1 matrix metalloproteinase, matrix metalloproteinase 2 and tissue inhibitor of metalloproteinase 2 in human cartilaginous tumors with special emphasis on mesenchymal and dedifferentiated chondrosarcoma. $J$ Cancer Res Clin Oncol, 125(10), 541-8. http://dx.doi.org/10.1007/s004320050314

Taniguchi, S., Fujiki, H., Kobayashi, H., Go, H., Miyado, K., Sadano, H., \& Shimokawa, R. (1992). Effect of (-)-epigallocatechin gallate, the main constituent of green tea, on lung metastasis with mouse B16 melanoma cell lines. Cancer Lett, 65(1), 51-4. http://dx.doi.org/10.1016/0304-3835(92)90212-E

Valcic, S., Timmermann, B. N., Alberts, D. S., Wächter, G. A., Krutzsch, M., Wymer, J., \& Guillén, J. M. (1996). Inhibitory effect of six green tea catechins and caffeine on the growth of four selected human tumor cell lines. Anticancer Drugs, 7(4), 461-8. http://dx.doi.org/10.1097/00001813-199606000-00011 
Yang, G. Y., Liao, J., Kim, K., Yurkow, E. J., \& Yang, C. S. (1998). Inhibition of growth and induction of apoptosis in human cancer cell lines by tea polyphenols. Carcinogenesis, 19(4), 611-6. http://dx.doi.org/10.1093/carcin/19.4.611

Yoon, S. O., Kim, M. M., \& Chung, A. S. (2001), Inhibitory effect of selenite on invasion of HT1080 tumor cells. J Biol Chem, 276(23), 20085-92. http://dx.doi.org/10.1074/jbc.M101143200 